\title{
Content Analysis of Shariah-Compliant Investment Equity Funds in KSA: Does Social Justice Matter?
}

\author{
Khaled O. Alotaibi ${ }^{1} \&$ Mohammad M. Hariri ${ }^{2}$ \\ ${ }^{1}$ College of Business Studies, The Public Authority for Applied Education and Tranning, Kuwait \\ ${ }^{2}$ College of Business, Umm Al Qura University, Kingdom of Saudi Arabia \\ Correspondence: College of Business Studies, The Public Authority for Applied Education and Tranning, Kuwait. \\ E-mail: Ko.alotaibi@paaet.edu.kw
}

Received: March 19, 2020

doi:10.5539/ijbm.v15n6p1

\author{
Accepted: April 24, 2020 \\ Online Published: May 10, 2020 \\ URL: https://doi.org/10.5539/ijbm.v15n6p1
}

\begin{abstract}
This paper examines the influence of capitalism and globalisation on the role of Shariah-Compliant Investment Funds (SCIFs) in promoting social justice in the Kingdom of Saudi Arabia (KSA) using content analysis method. This is to analyse the Terms and Conditions (T\&C) of SCIFs as they appear in Tadawul (Saudi stock market) in 2019 and compared with the findings in 2013. This research critically evaluates the findings of the content analysis through aspects of globalization and insights from the literature review. The content analysis shows that SCIFs in KSA are disjointed and decoupled from Islamic principles and do not fulfil the ideal social justice role in society.
\end{abstract}

Keywords: Shariah, Shariah-Compliant Investment Funds (SCIFs), Terms and Conditions, Social Justice, Globalization, Content Analysis, Socially Responsible Investment (SRI)

\section{Introduction}

One of the fundamental goals of Islamic teachings is to provide a system that delivers social justice and prosperity in human society (Hassan and Aliyu, 2018; Tapanjeh, 2009). The financial and investing system is one possible method to do so, as the Islamic religion contains several social justice concepts that work for social betterment and can be used in investment (Chapra, 2009). Seidu (2009) explains that "Islamic banking and finance is a system aimed at promoting Islamic economic order based on social justice" (p.38). This is because "in Islam, the humans' inner balance and relation with God depend on their ability to achieve social solidarity, unity and mutual respect among each other" (Kamla and Rammal, 2013, p.914). Despite that, little attention has been paid to social justice in the Islamic financial and investment literature.

Shariah-Compliant Investment Funds (SCIFs) are important for Islamic banking and finance as they allow small investors to achieve their goals of "seeking liquidity, portfolio diversification, and investment expertise" according to their moral, ethical and religious views (Merdad et al., 2010, p.158). This study is motivated by rapid growth and development in SCIFs market in the Gulf Cooperation Council (GCC) in general and in the Kingdom of Saudi Arabia (KSA) in particular. Furthermore, the KSA economy and stock market are the largest in the Middle East and the country is the largest crude oil producer and has the largest oil reserves. Hence, liquidity is increased and economic growth and stability are more pronounced (Gazdar et al., 2019). Therefore, Saudi Arabian and GCC economies in general can safeguard sustainable economic growth by systematic development of Islamic financial systems (Gazdar et al., 2019). However, SCIFs' development is in its infancy, but has expanded rapidly; there are a dearth of academic studies (Merdad et al., 2010; Bin Mahfouz and Hassan, 2012; and Ashraf, 2013). Additionally, there has been a constant growth of SCIFs in KSA but, as there is absence of government legislation that governs the industry, and a lack of studies about SCIFs, it is not clear whether these funds follow Shariah (Islamic law) completely or not. Although, Saudi Arabia follows Shariah as its main source for legislation in all life aspects, including the prohibition of pork, alcohol and gambling, some Islamic teachings, such as interest in banking and financial transactions, are not enforced by the government (Merdad et al., 2010).

Moreover, most studies in Islamic finance and investment focus on technical aspects such as calculating Zakat (Note 1) or avoiding Riba (Usury or interest), and performance (Mirza and Baydoun, 1999; Merdad et al., 2010; 
Bin Mahfouz and Hassan, 2012; and Ashraf, 2013) but usually miss discussing the social and ethical dimensions. This also applies to Socially Responsible investment (SRI) practices; Slager (2015) points out "the infusion of values beyond the technical requirements" (p. 396).

To date, to the best of the researchers' knowledge, no studies have been conducted to assess social justice and its influence on society, banking, or on conventional and Islamic investments (SCIFs). Thus, this research is unique in its scope because there is a lack of studies about SCIFs. Nevertheless, there are some studies on the social role of Islamic banking and finance that pave the way for this study, such as Maali et al. (2006) and Haniffa and Hudaib (2007), in addition to studies about socially responsible investment, such as Clark et al. (2015).

This study focuses on equity SCIFs and covers screening criteria based on Islamic teachings to see if there is any influence on social justice on society. This study will contribute to Islamic financial literature and SCIFs as this piece of work will be studied from a critical perspective. This paper will facilitate an understanding of whether or not there is a lack of social justice associated with the influence of SCIFs, how this can be enhanced by adapting screening criteria used by funds, and adoption of positive screening. Positive screening considers screening criteria embedded in Islamic teachings and this study will open the arguments of the improper practices and roles of SCIFs in KSA that impede social justice. In addition to the lack of studies focusing on the social role of, and social investment in, Islamic investment, there is also a dearth of a critical theoretical framework in the literature that help understanding the practice of SCIFs. All of the above has motivated this research to study SCIFs in KSA with a focus on globalization as a possible influence on the lack of social justice in SCIFs.

Therefore, based on these research motivations, the main concern of the paper is to examine the influence of capitalism and globalisation on the social justice aspects of Saudi SCIFs.

Practically, this paper critically examines: (i) if the Islamic concepts of social justice are reflected by the SCIFs T\&C; and (ii) if globalisation has influenced the SCIFs T\&Cs.

To answer these two empirical research questions, the current paper employs content analysis to analyse the content of 130 T\&Cs of SCIFs in KSA market as it appears in Tadawul in 2019 and compares the findings of T\&Cs of SCIFs in 2013 for the same content. This is to investigate how things have changed in this regard over the last seven years in KSA that witnessed remarkable transformation. The analysis is based on the impact of globalisation and, as the literature about the social role of SCIFs is scarce, SRI literature will be a source for critically assessing the findings as well.

The remainder of the paper is structured as follows. The next section covers the literature review and theoretical framework. The research method and data collection processes are outlined in the subsequent section. This is followed by the results of the analysis and discussion. The final section concludes.

\section{Literature Review}

Shariah emphasis on social justice can be found in the Quran and Sunnah. Likewise, several Islamic scholars have developed different thoughts about social theory in Islam in trying to spread social justice in society. For example, Imam Ibn Taimiyyah (1269 CE- $1328 \mathrm{CE}$ ) suggests starting an agency to create regulations to decrease unfair or unjust transactions in the market, as it is important for any Islamic financial and economic system "to provide justice, honesty and fairness and to ensure all parties their rights and dues" (Tapanjeh, 2009, p. 556). Islamic financial institutions should, therefore, cooperate and assist society to achieve social justice (Haniffa and Hudaib, 2007). However, there is no specific definition of social justice in Islam although there are a lot of concepts and principles that are related to social justice in Islamic teachings (Kamla and Rammal, 2013). Sayyid Qotb (1906 CE - 1966 CE) explains that there are three elements to social justice in Islam. These elements are "the absolute freedom of conscience, the complete equality of all men, and the social interdependence among members of the society" (Qotb and Shepard, 1996, p.16). In addition, Qotb (1996) mentions that social justice from the Islamic view consists of different concepts, such as mercy, love, help, and mutual responsibilities between Muslims and all human beings in general. Hassan (2007) defines social justice as the social status characterized by moral righteousness, fairness, and high levels of humanity and the equitable distribution of public resources.

Social justice is exercised in a system of law where every party enjoys its legal and moral rights (Hassan, 2007). According to Manage (2011) social justice implementation and measurement in the Saudi legal system is done in terms of equal opportunities for private activities, social privileges, and wealth distribution. In such approaches to social justice practice, the main factors that support the Saudi social justice are SCIFs regulatory bodies (Manage, 2011). Chapra (1979) explains that Shariah's objectives are to promote wisdom and the welfare of the people in 
this world; these are prioritised above profit and the wealth of one's self.

Therefore, in Islam, social justice contains several concepts and those that might be relevant to this paper are: equality; fairness; Takaful (social interdependence); brotherhood; Hisba (verification); mercy; Zakat; Sadqa (benevolence- charity); and Qard Hassan (loan without charging interest). According to Kuran (2004), the social justice principle depends upon applying the concepts of equality and fairness. The term 'equality' means that all people in the community should have the ability to have a good life, and requires the community to distribute its wealth equally. Abu-Tapanjeh (2009) explains that the absence of equality will lead to social injustice. The fairness and equality concepts in Islam mean prohibiting and preventing the oppression of people and helping the oppressed to obtain their rights so they can participate in social justice. Thus, equality and fairness should encompass Islamic finance to gain social justice (Dusuki, 2008).

Takaful (social interdependence) is important for social justice as it works to build a secure, united and peaceful society (Al-Alak, 2010). It means everyone in the society is required to help needy people to guarantee a level of basic human needs despite their religion or race (Al-Alak, 2010). Takaful can be financial or emotional. Financial Takaful is achieved by participating in covering one's financial issues and emotional Takaful is achieved through advice, friendship or sympathy (Obaidullah, 2005; Al-Alak, 2010; Abdullah, 2015). In financial Takaful (Islamic insurance), everyone provides money to a common fund. In specific circumstances, the participants in that fund are indemnified. In addition, any compensation must not be provided from outside the Takaful fund, which is what makes Takaful insurance different from conventional insurance (Abdullah, 2015). Hence, Takaful objectives are supported by the spirit of cooperation, social responsibility, brotherhood and social equality and thus, social justice in society (Abdullah, 2015).

The concept of brotherhood is like Takaful, but the difference is that whereas Takaful is about a group of people caring about one or more needy person, brotherhood is the personal relationship between two people that makes them care about each other. It is considered one of the important concepts for social justice (Chapra, 2009). Chapra explains that the brotherhood: "demands that all individuals be considered as equals and treated with dignity and respect, and that the fruits of development be shared equitably by all, irrespective of their race, colour, age, sex or nationality" $(2009$, p.2). Thus, brotherhood is based on the community principle; profit should not be the only thing when considering an investment.

Hisba (verification), which indicates an observation of community action to prevent unjust action, imposes social justice by applying the two important principles of equality and fairness (Kuran, 2004).

Mercy is also a concept of social justice in Islam. It emphasises tolerance and forgiveness. Investments, for instance, should not be at the expense of the health of the people, the environment or society (Obaidullah, 2005).

Zakat and Sadqa (non-obligatory charity) support social justice in society. Zakat is a powerful instrument in terms of achieving equality and social justice in the community, and helps to solve social and economic problems (Kuran, 2004; Ismail and Possumah, 2013). Zakat and Sadqa are two methods in Islam of fulfilling justice and fair of wealth distribution in society (Lewis, 2010). As a result, both can help to fulfil social justice, if allocated well.

Qard Hassan is the granting of a loan without charging interest (Lewis, 2001, Yaqub and Bello, 2012). Brown and Skully (2008) and Maali et al. (2006) explain that Qard Hassan is one of the methods for promoting social justice in Islamic finance as it can be used, for example, to finance microfinancial institutions or establish investment funds to provide people with Qard Hassan from the fund's profit.

In addition to the aforementioned social justice components of Islamic finance, Riba, prohibited (Haram) activities, Gharar and Mysir must be excluded from investments (Derigs and Marzban, 2008). These prohibitions support social justice, hence SCIFs should apply them when investing in investee companies and are called Shariah investment screening criteria.

To the best of the researchers' knowledge, no studies have empirically examined the impact of social justice on society in banking and finance and for conventional or SCIFs. Thus, this study depends to some extent on SRI literature, as there is a lot of synergy between SCIFs and SRI (see Ghoul \& Karam, 2007; Rigobert et al., 2012; Erragraguy \& Revelli, 2015). Despite SCIFs being based on divine law, that is perpetual and absolute, and SRI based on human ethical judgment, that may change over time (Hayat \& Kraeussl, 2011). In the same vein, Ariss (2010) explains that Islamic finance is appropriate for both Muslims and non-Muslims: "because of its socially responsible and ethical underpinnings, the new class of Islamic investments is appealing to both Muslims and non-Muslims who seek to invest in socially responsible products" (p.102). In addition, Rigobert et al. (2012) state that "Shariah compliant investment is often likened to SRI since their main goals are similar and both are 
screened" (p. 2). Therefore, Islamic investment is expected to fulfil not only the legal form, but also the substance of Shariah's ethical and moral objectives (Haniffa \& Hudaib 2007; Zakariyah, 2015).

Moreover, SRI screening criteria are one way to ensure social justice by SCIFs, from this study perspective. An appropriate definition of social justice by SCIFs is one identified by Kreander (2001), with some amendment. For the purpose of this study, social justice by SCIFs "does not rely solely on financial [screening] criteria in security selection, but uses ethical, [environmental, social, corporate governance or any other] non-financial [screening] criteria [that is in line with Islamic law and in achieving Islamic social justice,] when choosing securities [and thus to the betterment of society]" (Kreander, 2001, p.9).

The requirement of social justice by Shariah led to the establishment of supportive factors such as SCIFs. Such funds trace their history from the early 1990s (Hallerbach, et al., 2004).

Since Muslim investors prefer investment opportunities with acceptable performance and high compliance with Islamic ethics, SCIFs are one of the best option. SCIFs, "like any investment pooling system, collect individual savings for investment and the sharing of benefits" (Lewis, 2010, p.43).

SCIFs are a form of ethical investments; therefore, participating investors must adhere to Shariah principles (Derigs and Marzban, 2008; Hayat and Kraeussl, 2011; Mansour et al., 2015). It is the role of the Shariah supervisory board (SSB) and other regulatory bodies to ensure that any new company adheres to the principles and to approve the fund to invest in this institution (Hallerbach, et al., 2004: Hayat et al. 2013). SCIFs apply two types of screening criteria for choosing securities: (i) sector criteria; and (ii) financial criteria.

Sector guidelines outline which sectors can be allowed to practice prohibited activities and what should be done to counter the nature of Haram income (Dah and Wang, 2015). For instance, SCIFs in hotels are not allowed to offer night club services and alcoholic products. However, Shariah scholars allow some companies to obtain part of their income from prohibited activities according to predetermined financial tolerance criteria. Any Haram income should be given out for charities to purify the income (see Derigs \& Marzban, 2008; Dah and Wang, 2015; Hutchinson et al. 2018). Therefore, regulators monitor companies' business activities to ensure that they maintain compliance with Shariah guidelines and avoid Haram income from prohibited business activities (Haniffa \& Hudaib, 2007; Ho et al., 2012; Mansour et al., 2015; Ho, 2015). For this reason, each Islamic financial institution has a SSB to govern it and ensure that all its practices are in accordance with these guidelines (Derigs \& Marzban, 2008; Walkshäusl \& Lobe, 2012; Hayat et al. 2013). Their main responsibility is that each one "approves proposed [investee] companies and monitors the compliance of their business activities with the guidelines of the Shariah" (Walkshäusl \& Lobe, 2012, p.1). Sector and financial screening used by SCIFs are negative screens. Negative screening is the exclusion of firms that fail to comply with pre-defined criteria (Hallerbach, et al., 2004; Hutchinson et al., 2018). Negative screening recognises 'bad' companies, in order to avoid investing in them (Kreander, 2001). This type of screening is also referred to as 'sin screening' of industries (Schwartz, 2003). Negative screening is demonstrated through the strict prohibition of business activities that challenge Saudi social justice, which is based on Shariah.

Positive screening, on the other hand, involves the selection of firms that set good examples of socially friendly and supportive business activities, rather than excluding the firms (Clark et al., 2015). Such investment strategies should be manifest in Islamic fund investment decisions as these are key elements of Shariah. Dah and Wang (2015) argue that the current status of the role of SCIFs on KSA social justice is generally not developed. This is because the investments are focused on returns instead of focusing on social welfare, humankind, the community, and the environment. In fact, research also finds that social justice incorporating Environmental, Social and Governance (ESG) investment strategies often outperform comparable non-ESG strategies (see Clark et al., 2015; Erragraguy \& Revelli, 2015).

According to Denscombe, (2003), globalization plays a greater role than any other threat in the current inactivity of the role of SCIFs on KSA social justice. It is a fact that globalization has both negative and positive effects on national social-economic status. Some of the positive effects of globalization include technology diffusion, fair trade revolution, and easy learning and exchange of positive social values between society members, regulatory boards, and investors (Rodrigo, 2015), which can help SCIFs to develop through mutual learning between KSA and international investment funds. Rodrigo (2015) asserts that globalization has negative influences on the social justice roles of SCIFs' stakeholders, which includes investors, SSB members, investee companies, regulatory boards, and fund managers. Therefore, both sector and financial screening are based more on income than on social justice. SCIFs focus on terms such as 'performance' and 'financial returns' with little to no focus on words such as using positive screening related to social justice. Nainggolan et al (2011) attributed this problem to globalization. Also, Rodrigo (2015) argues that the collaboration between academia and the investment funds 
industry is weakening. Equity investment funds subscription has low customer satisfaction. The effects of globalization are the opposite of the normal expectations from a change that introduces new and advanced technology solutions for financial sectors and national growth. However, most Shariah scholars use these observations to describe globalization as a form of western attack on developing countries instead of reverse colonization (Rodrigo, 2015). (Note 2)

\section{Research Method}

The content analysis method is conducted into SCIFs' T\&Cs to examine if there is influence from globalisation on the T\&Cs' content that influences social justice. Krippendorf (2004) defines content analysis as " $\ldots$ a research technique for replicable and valid inferences from texts (or other meaningful matter) to the contexts of their use" (p. 18), being an important research method employed in the social sciences as Krippendorf (2004) notes: "the content analyst views data as representations not of physical events but of texts, images, and expressions that are created to be seen, read, interpreted, and acted on for their meanings, and must therefore be analysed with such uses in mind" (p. xiii). This is a method that involves classifying the text of written communication into different categories according to chosen criteria (Weber, 1985). A large amount of disclosure of a specific kind of information indicates the importance to users of the document or text. Also, if some information is hidden in the document, it can be discovered through this technique (Denscombe, 2003).

Content analysis is used widely in the finance and accounting fields, especially in social and/or environmental reporting, SRI investment funds studies, accounting education, narrative disclosures investigation, and examination of the content of codes of business ethics (see for instance: Guthrie \& Parker, 1989; Patten, 1992; Gray et al., 1995; Hackston \& Milne, 1996; Buhr, 1998; Milne \& Adler, 1999; Stone, 2001; Gaumnitz \& Lere, 2002; Dumay, 2015; Dunbar et al., 2016; Xie et al., 2019).

This study uses a 'form orientated' approach of content analysis (based on counting words) because "this approach reflects the notion that the more frequently a word or phrase is used, the greater is its importance to the area under investigation" (Ferguson et al., 2005, p.30). In addition, word counting helps to "contrast the results" (Carley, 1993, p. 81) and produce a better analysis of the results. To conduct the analysis, content analysis index was developed by using word count on all available T\&Cs for SCIFs, focusing on their T\&Cs.

\section{Analysis and Discussion}

The analysis is divided into four categories and critically assesses the extent of disclosure in each one to measure the level of social justice in SCIFs in KSA and to evaluate whether or not they are influenced by globalisation, and how that affects the role of SCIFs on social justice. The analysis compares the findings of two periods 2013 and 2019. (Note 3) The same content analysis index was applied for both years and the same material (T\&Cs) was used.

Table 1 lists the main terms related to social justice that could be in the T\&Cs of SCIFs, according to the literature and similar studies. These form the most important terms used in the Islamic finance and accounting literature. The terms chosen accord with similar studies that have employed content analysis (Maali et al., 2006; Othman et al., 2009; Aribi \& Gao, 2010; Rahman et al., 2010; El Mousaid \& Boutti, 2012; Adam et al., 2019; Ahmed et al., 2019). (Note 4)

Thus, being socially responsible means increasing businesses' accountability to the whole society (Kamla et al., 2006). Besides, considering issues related to the well-being of the society pertaining to interest and unfair trading practices like income distributions (Zakat) (see Othman et al., 2009). Zakat is an important element of Islamic finance and economics, as it is paid to the poor and needy (Note 5) (Farooq, 2008; Nainggolan, 2011). Kuran (2004) explains that most economists regard Zakat as a very powerful instrument in terms of achieving equality and social justice in the community, and it helps in solving social economic problems (Ismail and Possumah, 2013).

Likewise, purification is important, as some Shariah scholars allow investment in companies that have minor proportions of their revenues from forbidden activities (Hutchinson et al. 2018), but these require investors (or funds) to donate a proportion to charity, and this is what most SCIFs seem to be doing on behalf of investors. Thus, the funds will give part of the Haram income to charity, in order to 'purify' the revenue (Siddiqui, 2007), and such payment can be used for social justice. Regarding poverty, Dusuki (2008) explains that the most important dimension of Islamic banking and finance is that it aids the poor. Shariah principles require people to be concerned about poverty and the equal distribution of wealth to fulfil social justice (Rahman et al., 2010).

Another issue is Riba which is prohibited in Islam (Mirza \& Baydoun, 1999; Manage, 2011; Yaqub \& Bello, 2012). Mirza and Baydoun (1999) argue that Riba (usury) breaches the principle of social justice, in that it provides 
benefits to people who make no attempt to contribute to the risks of any project. Islamic equity funds are different from conventional ones, because they cannot invest in certain sectors, or pay or receive interest (see Hayat \& Kraeussl, 2011; Walkshäusl \& Lobe, 2012; Olson \& Zoubi, 2008, Hearn et al., 2012). As a result, prohibiting Riba in Islam is an obvious example of helping social justice (Rahman et al., 2010).

The words 'social' and 'ethics' were also added to the checklist because they are important, as Shariah emphasises ethical principles and promotes a moral code of behaviour, described by the Holy Qur'an and Sunnah toward every aspect of human activity including investment. Table 1 summarises the findings of the words and terms discussed above.

Table 1. Social justice disclosure

\begin{tabular}{|c|c|c|c|c|c|c|c|}
\hline \multicolumn{2}{|c|}{ Word } & \multirow{2}{*}{$\begin{array}{l}\text { Total Disclosure (2013) } \\
0\end{array}$} & \multirow{2}{*}{$\begin{array}{l}\text { No. of T\&Cs } \\
(\mathbf{2 0 1 3 )} \\
0\end{array}$} & \multirow{2}{*}{$\begin{array}{c}\% \\
0\end{array}$} & \multirow{2}{*}{$\begin{array}{l}\text { Total } \\
\text { Disclosure } \\
(2019) \\
0\end{array}$} & \multirow{2}{*}{$\begin{array}{l}\text { No. of } \\
\text { T\&Cs } \\
(2019) \\
0\end{array}$} & \multirow{2}{*}{$\begin{array}{l}\% \\
0 \\
0\end{array}$} \\
\hline 1 & Accountability & & & & & & \\
\hline 2 & Zakat & 14 & 10 & $14 \%$ & 573 & 113 & $87 \%$ \\
\hline 3 & Purification/Purified & 77 & 46 & $62 \%$ & 161 & 79 & $61 \%$ \\
\hline 4 & Poverty/Poverty alleviation & 0 & 0 & 0 & 0 & 0 & 0 \\
\hline 5 & Social/Social Justice/Social Responsibility/Social objective & 0 & 0 & 0 & 0 & 0 & 0 \\
\hline 6 & Riba (usury/interest/non-interest based) & 266 & 65 & $88 \%$ & 277 & 57 & $44 \%$ \\
\hline 7 & Islamic sources (Quran or Hadith) & 7 & 4 & $5 \%$ & 6 & 6 & $5 \%$ \\
\hline 8 & Ethics & 0 & 0 & 0 & 0 & 0 & 0 \\
\hline
\end{tabular}

Note. the table shows the important terms that refers to social justice in the Islamic finance literature. Word means: the specific word that the researcher looked for. Total disclosure means: the number of times that specific word is repeated in all T\&Cs. No of T\&Cs means: the specific word is repeated in only, for example, $10 \mathrm{~T} \& \mathrm{Cs}$ out of the total sample. \% means (column: No. of T\&Cs/total T\&Cs) $* 100$

As can be seen from Table 1, there is a lack of disclosure of Islamic themes related to social justice in Islam in both years of the study. For example, the word accountability was not found at all in any of the T\&Cs, nor was there any reference to a fund's accountability to Allah (God) or society. In addition, the word 'Zakat', which is very important in Islam, was mentioned only 14 times in only $14 \%$ of T\&Cs in 2013; however, in 2019, the word is increasingly mentioned in $87 \%$ of T\&Cs. This shows that the financial institutions realised the importance of clearing about Zakat to investors.

Purification was mentioned more often in the T\&Cs, featuring 77 times in 46 different T\&Cs in 2013, while in 2019 was mentioned in $79 \mathrm{~T} \& \mathrm{Cs}$, representing almost the same percentage according to the number of T\&Cs in each year. In more detail, for example, the 2013 purification process was mentioned with reference to the AlAhli Emerging Markets Trading Equity Fund (pp. 11-12):

"The Manager will determine the income generated from non-Sharia-compliant sources and will pay the amount to a separate account to be given to local charities by applying the following: Determine the non-Sharia-Compliant income amount for each company in the portfolio; Divide the above non-Sharia-Compliant income amount over the total number of the company's shares; Multiply the result of the above in to the actual number of shares the fund owns of that the company to come to the fund's share of the non-Sharia-Compliant income for that specific company; Repeat all the above for all companies where applicable and Pay the resulting amount to a separate account to be given to local charities".

While in 2019 for the same T\&Cs (p.39) it is shortened to:

"The Manager will determine the income generated from non-Sharia-Compliant sources and will pay the amount to a separate account to be given to local charities".

Thus, this finding appears to be more in tune with Islamic principles and concepts of social justice. While purification is not mentioned by all the funds, it is mentioned more than most other terms referring to social justice. The focus on purification might be due to the small number of fully Shariah-compliant investee companies in KSA and in the rest of the world (Wilson, 1997). Therefore, funds invest in companies that are mainly Shariah-compliant whose Haram earnings need purification. Purification as a word began to appear after Islamic financial institutions began to be allowed to invest in non-fully Shariah-compliant companies (Wilson, 1997; Derigs \& Marzban, 2009, Hoepner et al., 2011). Accordingly, the term 'purification' has become a word that is 
mentioned by SCIFs to give confidence to investors of their Islamic orientation and indicate that they are Shariah-compliant and worthy of trust and investment.

However, the word 'Riba', or 'interest', was mentioned more than any of the other words in 2013, and second in order after Zakat in 2019 as shown in Table 1. This accords with the focus on Riba and Zakat in the contemporary Islamic finance literature (Lewis, 2001; Manage, 2011; Yaqub \& Bello, 2012). Riba was mentioned 266 times in 2013 , in 65 T\&Cs, representing $88 \%$ of the sample. The nine funds that did not mention Riba were in financial institutions that operate only SCIFs exclusively and do not deal with conventional finance at all. In 2019 the number is almost the same in terms of word count, but mentioned in a smaller number of T\&Cs and that might be due to it being supposed as common sense for SCIFs.

Further, an interesting finding was that the term Hadith from the Islamic Sunnah occurs seven times in four T\&Cs in 2013 and six times in six T\&Cs in 2019. These Hadiths were mentioned in the financial criteria to explain the basis on which the ratio of the financial screening criteria was selected. The most interesting findings were that the usages of the term Hadith occurred in totally different SCIFs between 2013 and 2019, even though, most funds are still running from 2013.

However, the funds that mentioned the Hadith only explain that the 33\% ratio for Total Debt/Market Value of Equity (36 month average) was chosen because, according to the Hadith narrated by Sad Bin Abu Waqqas, the prophet Mohammad said about giving prosperity to charity after death "one third, yet even one third is too much" which indicates that, "in Islam, much equals a third" (Askari et al., 2010). Accordingly, the ratio should not be over a third (33\%). Hence, there is little or no concern for social justice, and the SCIFs' T\&Cs appear to be very similar to conventional ones in terms of only focussing on financial returns. In the same vein, Nainggolan et al. (2011), note that one of the reasons for that absence is that:

"Shari'ah is not a set of codified laws but rather a set of interpretations based on the Qu'ran, the Sunnah, and the opinion and consensus agreement of scholars" (Nainggolan et al., 2011, p. 2).

The findings in Table 1 highlight the issue of globalisation as there is poor disclosure of Islamic social justice concepts when it is compared to other words related to profit maximisation. The next section examines screening criteria of SCIFs and whether it increases social justice in KSA society.

\subsection{Screening Criteria}

The following Tables $(2,3$ and 4$)$ show the results for the three categories of terms that indicate any social justice screening criteria that SCIFs undergo prior to any investment being made, thus demonstrating that they are following Islamic principles. This section first investigates whether SCIFs use positive screening criteria similar to those used in SRI funds (Table 2) (Stone, 2001; Renneboog et al., 2011).

Table 2. Positive and SRI screening criteria related to social justice

\begin{tabular}{|c|c|c|c|}
\hline \multicolumn{2}{|c|}{ Environmental Items } & \multirow{2}{*}{$\begin{array}{l}\text { Total Disclosure } \\
0\end{array}$} & \multirow{2}{*}{$\begin{array}{l}\text { No. of T\&Cs } \\
0\end{array}$} \\
\hline 1 & Environment & & \\
\hline 2 & Climate & 0 & 0 \\
\hline 3 & Clean Technology/Renewable energy & 0 & 0 \\
\hline 4 & Pollution & 0 & 0 \\
\hline 5 & Clean energy & 0 & 0 \\
\hline 6 & Minimize environmental impact & 0 & 0 \\
\hline 7 & Disclose environmental policies and practices to shareholders, employees and community. & 0 & 0 \\
\hline 8 & Address their environmental performance & 0 & 0 \\
\hline \multicolumn{4}{|c|}{ Social items } \\
\hline 9 & Community relations/Development & 0 & 0 \\
\hline 10 & Sustainable living (health care) & 0 & 0 \\
\hline 11 & Human rights & 0 & 0 \\
\hline 12 & $\begin{array}{l}\text { Employer-employee relations/Labour relation. (For example, compensate their employees fairly, } \\
\text { good management relations, provide training for employees) }\end{array}$ & 0 & 0 \\
\hline \multicolumn{4}{|c|}{ Other Items } \\
\hline 13 & Direct engagement with companies & 0 & 0 \\
\hline
\end{tabular}

Note. 1) the table shows the positive screening criteria used by SRI fund (Renneboog et al., 2011; Stone, 2001) in USA and Europe and if these criteria are disclosed in KSA SCIFs' T\&Cs. 2) the table did not mention the different between 2013 and 2019 as the result is zero for both years. 
As shown in Table 2, there was no disclosure at all in any positive screening criteria in 2013 nor in 2019. This is a huge limitation of SCIFs in KSA because all these screening criteria form part of social justice and core parts of Islam and are also used in SRI investments. These screening criteria can be found in Islamic teachings, with great emphasis placed upon them.

It can be concluded that most SRI positive screening criteria exist in Islamic teachings; hence, SCIFs have no excuse for not using positive screening criteria in practice. In practice, SCIFs' investment processes depend upon negative screens, but they do not invest in companies that, for example, provide excellent working practices for their staff (Ballestero et al., 2011; Humphrey \& Lee, 2011). SCIFs should apply positive screens, as they are also sub group of SRI and such screens are commonly used in the SRI industry (Renneboog et al., 2011).

SCIFs could use globalisation practices to their advantage by mimicking SRI funds and establishing positive screening criteria to meet Islamic objectives. Globally, the most familiar ways to integrate environmental, social and governance (ESG) issues into investment practices is for SRI funds to use investment screening criteria and best-in-class approaches and engagement with companies (Capelle-Blancard \& Monjon, 2014; Erragraguy \& Revelli, 2015). Sparkes and Cowton (2004) propose that positive screening offers "the dual benefits of a commitment to sustainability plus the hoped-for financial benefits of investing in industries with significant long-term growth prospects" (p. 48). Accordingly, investments are made in companies with the best ESG performance (Clark et al. 2015), which will achieve financial and social justice goals.

The analysis suggests that SCIFs are not making enough effort to establish positive screening criteria to meet their Islamic principles or promote social justice since there are no changes between the findings of 2013 and 2019. The focus may only be on maximising profit, as an influence of globalisation and the West to compete with global financial institutions; for example, finance models assume that investors' goals are to maximise their returns for an agreed level of risk to "achieve a mean-variant efficient portfolio" (Humphrey and Lee, 2011, p.2).

Fund managers may provide excuses for themselves for not applying such criteria in the Saudi market as there are no indices that support having SRI screening criteria, unlike the fund managers in the US and Europe who have different indices that support this trend, such as: the Domini social index (US), Citizen social index (US), Calvert social index (US), and Dow Jones sustainability group index (world). Such indices could be established in KSA to mimic good Western investment practices (see Fang \& Foucart, 2014). In developed countries, SRI funds can use sustainability indices and benchmarks of companies' performance on ESG issues, for example, the FTSE4Good Index (Capelle-Blancard and Monjon, 2014; Slager, 2015). It would be possible to establish such an index for KSA, but this would need the initiative from influential groups of people, such as Shariah scholars and the Islamic financial institutions themselves, especially if it aimed to increase social justice in society. For example, fund managers could utilise positive screens with a "best in class" approach, ranking firms from every industry according to social criteria, similar to SRI funds.

Furthermore, SCIFs could mimic SRI funds by participating in shareholder activism for the common good (Lewis, 2001). Hence, fund managers could try to influence companies' behaviours by engaging in dialogue with management or by voting at annual general meetings (Renneboog \& Szilagyi, 2011; Becht et al., 2010). In addition, fund managers can engage with companies about ESG issues and deliver their voice, and use their rights as shareholders, either individually or collectively to influence and increase social justice in society (Sparkes \& Cowton, 2004; Capelle-Blancard \& Monjon, 2014; Clark et al., 2015).

\subsection{Negative Screening Criteria}

Table 3 covers the negative screening criteria in the T\&Cs of the SCIFs in the KSA, reflecting social justice in Islam because they focus on eliminating investment in companies that have a negative influence on society. The frequency of words refers to the importance of this item to the SCIFs. To examine whether SCIFs fund managers are applying these negative screening criteria for a social justice role, the consistency of the negative screening criteria between the T\&Cs of the SCIFs is examined. The absence of consistency will indicate that these negative screening criteria are not designed to foster social justice, but only to have documents which comply with marketing the SCIFs; in other words, they are influenced by the negative side of globalisation. 
Table 3. Negative screening

\begin{tabular}{|c|c|c|c|c|c|c|c|}
\hline \multicolumn{2}{|c|}{ Items } & \multirow{2}{*}{$\begin{array}{l}\text { Total Disclosure } \\
\mathbf{( 2 0 1 3 )}\end{array}$} & \multirow{2}{*}{$\begin{array}{l}\begin{array}{l}\text { No. of } \\
\text { T\&Cs }\end{array} \\
49\end{array}$} & \multirow{2}{*}{$\begin{array}{l}\text { \% } \\
66 \%\end{array}$} & \multirow{2}{*}{$\begin{array}{l}\text { Total } \\
\text { Disclosure } \\
(\mathbf{2 0 1 9 )}\end{array}$} & \multirow{2}{*}{$\begin{array}{l}\text { No. of } \\
\text { T\&Cs }\end{array}$} & \multirow{2}{*}{$\begin{array}{l}\text { \% } \\
71 \\
\%\end{array}$} \\
\hline 1 & Alcohol & & & & & & \\
\hline 2 & Gambling & 69 & 48 & $65 \%$ & 116 & 81 & $\begin{array}{l}62 \\
\%\end{array}$ \\
\hline 3 & Tobacco & 62 & 50 & $67 \%$ & 104 & 86 & $\begin{array}{l}66 \\
\%\end{array}$ \\
\hline 4 & $\begin{array}{l}\text { Conventional financial banks/commercial } \\
\text { banks/non-Shariah compliant Financial services }\end{array}$ & 54 & 48 & $65 \%$ & 56 & 37 & $\begin{array}{l}28 \\
\%\end{array}$ \\
\hline 5 & Pork and its derivatives & 50 & 50 & $67 \%$ & 103 & 87 & $\begin{array}{l}67 \\
\%\end{array}$ \\
\hline 6 & Production and distribution of pornographic films & 43 & 43 & $58 \%$ & 95 & 79 & $\begin{array}{l}61 \\
\%\end{array}$ \\
\hline 7 & $\begin{array}{l}\text { Use of non-Islamic financial instruments such as Futures } \\
\text { contracts, options contracts, SWAPs and preferred stocks. }\end{array}$ & 41 & 41 & $55 \%$ & 33 & 33 & $\begin{array}{l}25 \\
\%\end{array}$ \\
\hline 8 & $\begin{array}{l}\text { Satellite channels and cinemas/media/theatres and cinema } \\
\text { industry }\end{array}$ & 35 & 35 & $47 \%$ & 72 & 72 & $\begin{array}{l}55 \\
\%\end{array}$ \\
\hline 9 & $\begin{array}{l}\text { Hotels and places of entertainment that provide prohibited } \\
\text { services/Management of casinos/Leisure }\end{array}$ & 33 & 33 & $44 \%$ & 62 & 62 & $\begin{array}{l}48 \\
\%\end{array}$ \\
\hline $\begin{array}{l}1 \\
0\end{array}$ & Restaurants that provide prohibited services & 32 & 31 & $43 \%$ & 55 & 55 & $\begin{array}{l}42 \\
\%\end{array}$ \\
\hline $\begin{array}{l}1 \\
1\end{array}$ & Traditional insurance companies & 31 & 30 & $40 \%$ & 60 & 60 & $\begin{array}{l}46 \\
\%\end{array}$ \\
\hline $\begin{array}{l}1 \\
2\end{array}$ & $\begin{array}{l}\text { Production and distribution of meat not slaughtered } \\
\text { according to Shariah rules }\end{array}$ & 30 & 30 & $40 \%$ & 52 & 52 & $\begin{array}{l}40 \\
\%\end{array}$ \\
\hline $\begin{array}{l}1 \\
3\end{array}$ & Weapon/Arms & 22 & 22 & $30 \%$ & 32 & 32 & $\begin{array}{l}25 \\
\%\end{array}$ \\
\hline $\begin{array}{l}1 \\
4\end{array}$ & Books and magazines/advertising (Note 6) & 21 & 21 & $28 \%$ & 70 & 70 & $\begin{array}{l}54 \\
\%\end{array}$ \\
\hline $\begin{array}{l}1 \\
5\end{array}$ & Nuclear energy/nuclear weapons & 0 & 0 & 0 & 0 & 0 & 0 \\
\hline
\end{tabular}

Note. The table shows the negative screening criteria used in SCIFs in KSA. Total disclosure means: the number of times that specific item is repeated in all T\&Cs. No. of T\&Cs means: the specific item is repeated on only, for example, 49 T\&Cs out of the total sample. \% means (column: No. of T\&Cs/total T\&Cs) $* 100$

Source: SCIFs T\&Cs in KSA.

As can be seen from Table 3, negative screening criteria were disclosed in almost all SCIFs, but the focus differed across the various T\&Cs.

Negative screening of Islamic financial institutions began because not many companies are following Islamic rules completely. For this reason, Shariah scholars started introducing parameters. For example, no companies in SCIFs may have any prohibited activity, such as alcohol, pork, gambling, entertainment, tobacco and armaments (Brown \& Skully, 2009); this is called negative screening. These companies may be harmful to society in both short and long term, and may thus have negative consequences: in general, their activities are out of line with a fund's values and beliefs (Kreander, 2001), and in this paper context would affect social justice. The SCIFs in this study at least seem to be doing the minimum by applying (only) negative screening. Kreander (2001) called such funds commercial funds that merely wished to satisfy the beliefs of a few people without making any improvements to society.

The results show that SCIFs in KSA do not have consistency or a standard method for presenting their negative screening because these differed from one set of T\&Cs to another. They differed in two aspects: i) the way in which they are presented to investors; and ii) the criteria differ from fund to fund, as some funds explain their screening criteria while others merely mention the word. For example, the AlAhli GCC Trading Equity Fund (2013) stated 
that it could not invest in companies "operating movie theatres and the cinema industry and creating, publishing, or distributing pornography" (p. 11), but SAMBA Al Nafees Global Commodities Equity Fund (2013) has different $T \& C s$ and provides a wider set of information because it defines each element. The difference in the presentation of negative screening criteria may not be an important issue but it suggests that fund managers are only presenting that information to convince investors that the fund is Shariah-compliant.

The screening criteria disclosures are sometimes inappropriate for a particular market. For example, the HSBC Saudi equity fund's (2013 and 2019) screening criteria mention "gambling and pornography" (p. 18), but these two industries do not exist in the Saudi stock market as they are considered illegal. Meanwhile, the HSBC Amanah Europe equity fund (2013) does not mention "pornography" as one of its screening criteria, although this is available in Europe however HSBC remedy this error in 2019 T\&Cs issues.

\subsection{Western Principles of Profit and Performance}

This section is concerned with analysing the findings related to disclosing words that indicate a focus on maximising profit rather than having social-related objectives. Table 4 provides a summary of the items in this category and the total number of disclosures.

Table 4. Performance and profit terms in T\&Cs

\begin{tabular}{|c|c|c|c|c|c|}
\hline \multicolumn{2}{|c|}{ Word } & \multirow{2}{*}{$\begin{array}{l}\text { Total Disclosure (2013) } \\
830\end{array}$} & \multirow{2}{*}{$\begin{array}{l}\text { No. of T\&Cs } \\
73\end{array}$} & \multirow{2}{*}{$\begin{array}{l}\text { Total Disclosure (2019) } \\
5791\end{array}$} & \multirow{2}{*}{$\begin{array}{l}\text { No. of T\&Cs } \\
130\end{array}$} \\
\hline 1 & Performance & & & & \\
\hline 2 & Return (financial returns) & 267 & 73 & 1778 & 130 \\
\hline 3 & Profit / profitability & 244 & 67 & 2365 & 130 \\
\hline
\end{tabular}

Note. The table shows the words repeated in T\&Cs.

As shown in Table 4, the funds focus on performance, return and profit. The terms 'return' and 'performance' were mentioned in all but one fund's objectives in 2013, indicating that they were important to the funds. Nevertheless, looking for profit is legitimate in Shariah and is a privilege for everyone except when it happens at the expense of ethics, morals and social justice. In addition, competition, hard work, and taking risks in business are important values in Islam, achievable only by adhering to the Islamic faith and promoting social and economic justice (Askari et al., 2010). For example, the findings relating to positive screening criteria show a lack of focus on words referring to social justice concepts, while this section's findings show that the spotlight is on words referring to performance, profit and financial returns. Thus, the absence of positive screening in SCIFs and the focus only on profit and financial returns might be one of the reasons for SCIFs' lack of a social justice; focussing results from the influence of globalisation on SCIFs investment stakeholders makes them adopt the Western investment paradigm. Iqbal notes that the Western financial system is very different from the Islamic financial system "because of the different nature and treatment of financial instruments" (1997, p. 44), and that can cause many contradictions when Western countries work to develop Islamic finance.

The word 'performance' was the most frequently mentioned word, either in 2013 or 2019 , in T\&Cs, as well as being mentioned in same funds' objectives; for example, the HSBC Amanah Saudi Freestyle Equity Fund mentioned that "...The performance of the fund will not be linked to a benchmark..." (2013, p.8). Financial return was mentioned in most occasions in (2013) and (2019) T\&Cs. For unclear reasons, the only T\&Cs that did not mention the word 'return' was 'Alnifea T\&Cs (2013) for Saudi equities', although the T\&Cs were detailed and mention the word 'performance' several times . For example, the AlAhli US Trading Equity Fund mentioned it in its fund objective:

“... long term capital growth, the Fund seeks to achieve competitive returns during the medium to long term (5 years or more) through investing selectively in US companies that have low debt ratios and comply with the Fund's investment strategy" (2013, p. 3).

Finally, the word 'profit' was mentioned 244 times in 67 T\&Cs in 2013, while mentioned 2,365 times in 130 T\&Cs in 2019. The word profit was used to inform investors that the fund was not always going to make a profit due to investment risk. For example, the AlAhli Europe Trading Equity Fund mentioned that "Investors in the Fund are not certain to make a profit and may suffer a loss, and therefore may not recover their fully-invested capital" (2013, p.4). The findings indicate that these items are far more important for SCIFs than anything related to Islamic principles or social justice; they are repeated more often than the words in the previous sections.

The focus on performance in the T\&Cs is an example of how SCIFs mimic conventional Western funds. Islamic 
finance, in general, focuses on financial returns and ignores other aspects, such as social justice. This accords with Ariss (2010), who explains that:

"...Islamic finance mandates a return on capital. However, this return on capital depends greatly on the performance of the activity being financed." (p. 102).

The focus on maximising profit in SCIFs is a result of the pressure from global financial institutions and investors. Rigobert et al (2012) explain that Muslim investors seek investments that both comply with Islamic ethics and, perhaps more importantly, also offer acceptable performance. KSA Shariah-compliant funds' investors do not use globalisation's advantages for SRI objectives, as global SRI investors play an important role in shifting the focus of companies towards having a better influence on society.

SRI funds also often offer investors adequate financial returns and performance. As Clark et al. (2015) explain, SRI studies that focus on comparing the performance and financial returns of SRI with conventional investments find that there are no differences between them. The financial institutions in KSA can use positive screening, at least, as a business case "to attract socially and environmentally concerned customers and by beliefs that SRI delivers higher return on a given level of risk" (Jansson \& Biel, 2011, p. 2). Several studies that have explored SRI investment funds compared with conventional funds have shown that SRI themselves might also be financially motivated (see Derwall et al., 2005; Kreander et al., 2005; Clark et al., 2015). The mentality of Islamic financial institutions remains undeveloped; just as at the start of SRI funds in Europe when there was disagreement about SRI funds which used negative screens, and the limited investment opportunities that caused whole industries to be excluded from the funds' portfolios. Consequently, diversified portfolios with unconstrained investment opportunities are impossible (Hallerbach et al., 2004; Statman \& Glushkov, 2009; Humphrey \& Lee, 2011), but recently SRI funds' growth has increased as a result of improvements in the investment approach of SRI funds. Thus, SCIFs could avoid the negative influences and adapt the positive influences of globalisation by applying positive screening criteria, to open up a new, untouched area of the KSA market and increase social justice in society, as there should be no conflict between having social justice and providing investors with adequate performance and financial returns.

\section{Conclusion}

This research aimed to fill the gap in the Islamic investment literature, as it tries to investigate SCIFs' T\&Cs concerns about social justice, and whether globalisation has an influence on their content. The findings of the T\&Cs content analysis show that SCIFs in KSA are decoupled from Islamic principles and do not fulfil a social justice role in society as it should. The analysis shows that SCIFs' T\&Cs do not focus on words that reflect Islamic practices of social justice. Thus, social justice is not reflected in SCIFs' T\&Cs. The most frequent Islamic words mentioned are Zakat and Riba, but other words referring to a social justice role by SCIFs such as accountability are not mentioned. The results confirm a complete absence of any positive screening criteria. Obaidullah (2005) notes that most of this detailed information is absent from SCIFs' prospectuses and annual reports, and hence affects the influence of social justice on their practices as they are invisible, which is similar to the finding that social justice concepts are absent from SCIFs.

The difference in the T\&Cs of the same fund managers means that T\&Cs do not reflect the basic concepts of social justice. In the same manner, the T\&Cs do not embrace Islamic concepts of social justice but focus on performance and financial returns. In addition, using Western indices, and by not providing satisfactory information about SSBs members, these SCIFs do not focus on social justice. SCIFs arguably have adopted a western style of fund management by repackaging conventional financial products in order to attract Islamic investors (Fang \& Foucart, 2014). It seems that the Western capitalistic influence in KSA has built a culture of maximising returns (Humphrey \& Lee, 2011). As a result of globalisation, SCIFs in KSA adopt very similar investment styles to the West but badge them under a different name; they do not follow the positive features of SRI screening criteria, such as screening criteria.

No doubt that KSA, with its oil reserves and strong economic and political relationships with the USA and UK, has been heavily influenced by globalisation (Fox et al., 2006). One of the consequences of that relationship is adopting American and British accounting models in KSA, and that has also influenced Islamic finance practices. Thus, globalisation has caused SCIFs to lack positive screening criteria to fulfil social justice and hence to lack a social justice focus.

However, SCIFs can support Saudi social justice through the spirit of fairness and social equality, and practice the real meaning of Islam, if investment policy focuses on social justice in addition to economic benefits. 


\section{References}

Abdullah, S. (2015). The Objectives of Takaful and Shariah: Towards the Achievement of Maqasid Shariah. Journal of Human Capital Development, 8(1), 93-104.

Abu-Tapanjeh, A. M. (2009). Corporate governance from the Islamic perspective: A comparative analysis with OECD principles. Critical Perspectives on Accounting, 20(5), 556-567.

Adam, N. L., Bakar, N. A., Soh, S. C., \& Purai, A. J. (2019). Shariah Compliant Web Analysis Tool. In Contemporary Management and Science Issues in the Halal Industry (pp. 29-35).

Ahmed, E. R., Islam, A., \& Amran, A. B., (2019), Examining the legitimacy of Sukuk structure via Shariah pronouncements. Journal of Islamic Marketing, 10(4) 1151-1166.

AlAhli Emerging Markets Trading Equity Fund T\&Cs. (2008).

AlAhli Emerging Markets Trading Equity Fund T\&Cs. (2019).

Al-Alak, B., \& Eletter, S. (2010). Islamic Entrepreneurship: An Ongoing Driver for Social Change. Interdisciplinary Journal of Contemporary Research of Business, 1(12), 81-97.

Aribi, Z. A., \& Gao, S. (2010). Corporate social responsibility disclosure: a comparison between Islamic and conventional financial institutions. Journal of Financial Reporting and Accounting, 8(2), 72-91.

Ariss, R. T. (2010). Competitive conditions in Islamic and conventional banking: A global perspective", Review of Financial Economics, 19(3), 101-108.

Askari, H., Iqbal, Z., \& Mirakhor, A. (2010). Globalization and Islamic Finance: Convergence, Prospects and Challenges. Singapore: John Wiley \& Sons (Asia).

Ballestero, E., Bravo, M., Pérez-Gladish, B., Arenas-Parra, M., \& Plà-Santamaria, D. (2011). Socially Responsible Investment: A multi criteria approach to portfolio selection combining ethical and financial objectives. European Journal of Operational Research, 216(2), 487-494.

Becht, M., Franks, J., Mayer, C., \& Rossi, S. (2010). Returns to shareholder activism: Evidence from a clinical study of the Hermes UK Focus Fund. Review of Financial Studies, 23(3), 3093-3129.

Bin Mahfouz, S., \& Hassan, M. K. (2012). A Comparative Study between the Investment Characteristics of Islamic and Conventional Equity Mutual Funds in Saudi Arabia. The Journal of Investing, 21(4), 128-143.

Brown, K., \& Skully, M. (2009). Ethical Investments and Performance of Islamic Banks. Journal of Islamic Economics, Banking and Finance, 5(1), 59-72.

Buhr, N. (1998). Environmental Performance, Legislation and Annual Report Disclosure: The Case of acid Rain and Falconbridge. Accounting, Auditing and Accountability Journal, 11(2), 163-190.

Capelle-Blancard, G. \& Monjon, S. (2014). The Performance of Socially Responsible Funds: Does the Screening Process Matter? European Financial Management, 20(3), 494-520.

Carley, K. (1993). Coding choices for textual analysis: A comparison of content analysis and map analysis. Sociological methodology, 23, 75-126.

Chapra, M. U. (1979). The Islamic Welfare State and its Role in the Economy. Islamic Foundation.

Chapra, U. (2009). Ethics and Economics: an Islamic Perspective. Islamic Economic Studies, 16(1), 1-24

Clark, G. L., Feiner, A., \& Viehs, M. (2015). From the Stockholder to the Stakeholder: How Sustainability Can Drive Financial Outperformance. Retrieved from http://www.arabesque.com

Dah, M., Hoque, M., \& Wang, S. (2015). Constrained investments and opportunity cost - evidence from Islamic funds. Managerial Finance, 41(4), 348-367.

Denscombe, M. (2003). The Good Research Guide: for Small-Scale Social Science Research Projects (2nd ed.). Maidenhead: Open University Press.

Derigs, U., \& Marzban, S. (2008). Review and analysis of current Shariah-compliant equity screening practices. International Journal of Islamic and Middle Eastern Finance and Management, 1(4), 285-303.

Derwall, J., Guenster, N., Bauer, R., \& Koedijk, K. (2005). The eco-efficiency premium puzzle. Financial Analysts Journal, 61(2), 51-63.

Dumay, J., \& Cai, L. (2015). Using content analysis as a research methodology for investigating intellectual capital disclosure: A critique. Journal of Intellectual Capital, 16(1), 121-155. 
Dunbar, K., Laing, G., \& Wynder, M. (2016). A content analysis of accounting job advertisements: Skill requirements for graduates. e-Journal of Business Education and Scholarship Teaching, 10(1), 58-72.

Dusuki, A. W. (2008). Banking for the poor: the role of Islamic banking in microfinance initiatives. Humanomics, 24(1), 49-66.

El Mousaid, F., \& Boutti, R. (2012). Relationship between corporate social responsibility and financial performance in Islamic banking. Research Journal of Finance and Accounting, 3(10), 93-103.

Erragraguy, E., \& Revelli, C. (2015). Should Islamic investors consider SRI criteria in their investment strategies? Finance Research Letters, 14, 11-19.

Fang, E. S., \& Foucart, R. (2014). Western financial agents and Islamic ethics. Journal of Business Ethics, 123(3), 475-491

Farooq, M. (2008). The challenge of poverty and the poverty of Islamic economics. Journal of Islamic Economics, Banking and Finance, 4(2), 35-58.

Ferguson, J., Collison, D., Power, D., \& Stevenson, L. (2005). What are recommended accounting textbooks teaching students about corporate stakeholders? The British Accounting Review, 37, 23-46.

Fox, J., Mourtada-sabbah, N., \& Al-mutawa, M. (2006). Globalization and the Gulf. London: Routledge.

Gaumnitz, B. R., \& Lere, L. C. (2002). Contents of Codes of Ethics of Professional Business Organisations in the United States. Journal of Business Ethics, 35, 35-49.

Gazdar, K., Hassan, M. K., Safa, M. F., \& Grassa, R. (2019). Oil price volatility, Islamic financial development and economic growth in Gulf Cooperation Council (GCC) countries. Borsa Istanbul Review, 19(3), 197-206

Ghoul, W. and Karam, P. (2007). MRI and Sri mutual funds: A comparison of Christian, Islamic (morally responsible investing), and socially responsible investing (SRI) mutual funds. Journal of Investing, 16(2): 96-102.

Gray, R. H., Kouhy, R., \& Lavers, S. (1995). Corporate Social and Environmental Reporting: A Review of the Literature and a Longitudinal Study of UK Disclosure. Accounting, Auditing and Accountability Journal, $8(2), 47-77$.

Guthrie, J., \& Parker, L. D. (1989). Corporate Social Reporting: A Rebuttal of Legitimacy Theory. Accounting and Business Research, 9(76), 343-352.

Hackston, D., \& Milne, M. (1996). Some Determinants of Social and Environmental disclosures in New Zealand. Accounting Auditing and Accountability Journal, 9(1), 77-108.

Hallerbach, W., Ning, H., Soppe, A., \& Spronk, J. (2004). A framework for managing a portfolio of socially responsible investments. European Journal of Operational Research, 153(2), 517-529.

Haniffa, R., \& Hudaib, M. (2007). Exploring the Ethical Identity of Islamic Banks via Communication in Annual Reports. Journal of Business Ethics, 76, 97-116.

Hassan, M. K., \& Aliyu, S. (2018). A contemporary survey of Islamic banking literature. Journal of Financial Stability, 34, 12-43.

Hassan, S. 2007, the Islamic concept of social justice: Its possible contribution to ensuring harmony and peaceful coexistence in a globalized world, Macquarie Law Journal, 7, 167 - 183.

Hayat, R., \& Kräussl, R. (2011). Risk and return characteristics of Islamic equity funds. Emerging Markets Review, 12(2), 189-203.

Hayat, R., Butter, F. D., \& Kock, U. (2013). Halal certification for financial products: A transaction cost perspective. Journal of Business Ethics, 117, 601-613.

Hearn, B., Piesse, J., \& Strange, R. (2012). Islamic finance and market segmentation: Implications for the cost of capital. International Business Review, 21(1), 102-113.

Ho, C. (2015). International comparison of Shari'ah compliance screening standards. International Journal of Islamic and Middle Eastern Finance and Management, 8(2), 222-245.

Ho, C., Masood, O., Abdul Rehman, A., \& Bellalah, M. (2012). Syariah accounting and compliant screening practices. Qualitative Research in Financial Markets, 4(2), 240-254.

Hoepner, A. G., Rammal, H. G., \& Rezec, M. (2011). Islamic mutual funds' financial performance and international investment style: Evidence from 20 countries. The European Journal of Finance, 17(9-1), 
$829-850$

Hong, H., \& Kacperczyk, M. (2009). The price of sin: The effects of social norms on markets. Journal of Financial Economics, 93(1), 15-36.

Humphrey, J. E., \& Lee, D. D. (2011). Australian socially responsible funds: Performance, risk and screening intensity. Journal of Business Ethics, 102(4), 519-535.

Hutchinson, M.C., Mulcahy, M., \& O’Brien, J. (2018). What is the cost of faith? An empirical investigation of Islamic purification. Pacific-Basin Finance Journal, 52, 134-143.

Iqbal, Z. (1997). Islamic financial systems. Finance and Development, 34, 42-45.

Ismail, A. G., \& Possumah, B. T. (2013). Theoretical Model for Zakat-Based Islamic Microfinance Institutions in Reducing Poverty. International Research Journal of Finance and Economics, 103, 136-150.

Jansson, M., \& Biel, A. (2011). Motives to engage in sustainable investment: a comparison between institutional and private investors. Sustainable Development, 19(2), 135-142.

Kamla, R., \& Rammal, H. G. (2013). Social Reporting by Islamic Banks: Does Social Justice Matter? Accounting, Auditing \& Accountability Journal, 26(6), 911-945.

Kamla, R., Gallhofer, S., \& Haslam, J. (2006). Islam, Nature and Accounting: Islamic Principles and the Notion of Accounting for the Environment. Accounting Forum, 30(3), 245-265.

Kreander, N. (2001). An analysis of European ethical funds. ACCA Occasional Research Paper 33. Certified Accountants Educational Trust.

Kreander, N., Gray, R. H., Power, D. M., \& Sinclair, C. D. (2005). Evaluating the performance of ethical and non-ethical funds: a matched pair analysis. Journal of Business Finance and Accounting, 32, 1465-1493.

Krippendorff, K. (2004). Content analysis: An Introduction to its methodology (2nd ed.). London: Sage.

Kuran, T. (2004). Islam and Mammon: The Economic Predicaments of Islamism. Oxfordshire: Princeton University Press.

Lewis, M. K. (2001). Islam and accounting. Accounting Forum, 25(2), 103-127.

Maali, B., Casson, P. and Napier, C. (2006). Social reporting by Islamic banks. ABACUS, 42(2), 266-289.

Manage, A. J. B. (2011). Islamic banking and prohibition of Riba/interest. African Journal of Business Management, 5(5), 1763-1767.

Michelson, G., Wailes, N., Van Der Laan, S., \& Frost, G. (2004). Ethical investment processes and outcomes. Journal of Business Ethics, 52, 1-10.

Milne, M. J., \& Adler, R. W. (1999). Exploring the reliability of social and environmental disclosures content analysis. Accounting, Auditing and Accountability Journal, 12(2), 237-256.

Mirza, M and Baydoun, N. (1999). Do Islamic societies need their own accounting and reporting standards? Journal of the Academy of Business Administration, 2, 39-45.

Nainggolan, Y., How, J., \& Verhoeven, P. (2011). Do Fund Managers Keep Their Promises? The Case of Shari'ah Equity Funds. Financial Markets and Corporate Governance Conference.

Obaidullah, M. (2005). Islamic financial services. Jeddah: Islamic Economic Research Center, KAU.

Olson, D., \& Zoubi, T. A. (2008). Using accounting ratios to distinguish between Islamic and conventional banks in the GCC region. The International Journal of Accounting, 43(1), 45-65.

Othman, R., Thani, A. M., \& Ghani, E. K., (2009). Determinants of Islamic social reporting among top Shariah-approved companies in Bursa Malaysia. Research Journal of International Studies, 12(10), 4-20.

Patten, D. M. (1992). Intra-industry Environmental Disclosures in Response to the Alaskan Oil Spill: A Note on Legitimacy Theory. Accounting, Organisations and Society, 17(5), 471-475.

Qotb, S., \& Shepard, W. E. (1996). Sayyid Qutb and Islamic Activism: A Translation and Critical Analysis of Social Justice in Islam.

Rahman, A. A., Yahya, M. A., \& Nasir, M. H. M. (2010). Islamic norms for stock screening: A comparison between the Kuala Lumpur Stock Exchange Islamic Index and the Dow Jones Islamic Market Index. International Journal of Islamic and Middle Eastern Finance and Management, 3(3), 228-240.

Renneboog, L., and Szilagyi, P. G. (2011). The role of shareholder proposals in corporate governance. Journal of 
Corporate Finance, 17(1), 167-188.

Renneboog, L., Ter Horst, J., \& Zhang, C. (2011). Is ethical money financially smart? Nonfinancial attributes and money flows of socially responsible investment funds. Journal of Financial Intermediation, 20(4), $562-588$.

Rigobert, M. J., Ben Salah, M., \& Jouaber, K. (2012). The performance of Islamic investment: evidence from the Dow Jones Islamic indexes.

Rodrigo, K. (2015). Globalization and the Saudi Arabian culture. The Write Pass Journal, 3(2), 128-129.

Schwartz, M. (2003). The "Ethics" of ethical investing. Journal of Business Ethics, 43, 195-213.

Seidu, A. M. (2009). Current Global Financial Crisis: Cause and Solution. International Financial Crisis, 26

Siddiqui, R. (2007). Shari'ah compliance, performance, and conversion: The case of the Dow Jones Islamic market Index. Chicago Journal of International Law, 495-519.

Sparkes, R., \& Cowton, C. (2004). The maturing of socially responsible investment: a review of the developing link with corporate social responsibility. Journal of Business Ethics, 52, 45-57.

Statman, M., \& Glushkov, D. (2009). The wages of social responsibility. Financial Analysts Journal, 33-46.

Stone, B. A. (2001). Corporate Social Responsibility and Institutional Investment. Business and Society, 40(1), $112-117$.

Walkshäusl, C., \& Lobe, S. (2012). Islamic Equity Investing: Alternative Performance Measures and Style Analysis. The Journal of Investing, 21(4), 182-189.

Weber, R. P. (1985). Basic Content Analysis. Beverly Hills: Sage Publications.

Wilson, R. (1997). Islamic finance and ethical investment. International Journal of Social Economics, 24, 11.

Xie, X., Huo, J., \& Zou, H. (2019).Green process innovation, green product innovation, and corporate financial performance: A content analysis method. Journal of Business Research, 101, 697-706.

Yaqub, J. O., \& Bello, H. T. (2012). Applicability of Chapra's Model of Islamic Banking in Nigeria. European Scientific Journal, 8, 15.

Zakariyah, L. (2015). Harmonising legality with morality in Islamic banking and finance: A quest for Maqāșid alSharı̄'ah paradigm. Intellectual Discourse, 23(Special Issue), 355-376.

\section{Notes}

Note 1. Zakat is a religious obligation as required in the Holy Qur'an and is one of the five pillars of Islam. It is must be paid once a year.

Note 2. Also see Fang and Foucart (2014).

Note 3. The number. of SCIFs in T\&Cs in 2013 was 74, while in 2019 there were 130 T\&Cs.

Note 4. However, most of these studies used annual reports. To conduct this study, first, the annual reports of fund managers' in KSA were selected, but many were unavailable and those that were included a lot of information that was unrelated to SCIFs. The availability of T\&Cs was then assessed and because of their relevance and availability they were chosen for this study.

Note 5. Zakat is not only distributed to for the poor and needy. "Indeed, only three of the eight categories strictly relate to the poor and needy. The other five (those who are engaged in Zakat collection, those whose hearts need to be won over, those who are in debt, the wayfarer, and those who are in the path of Allah) may or may not have anything to do with poverty. There is also no consensus that the poor or needy have priority over other categories, especially if at any particular time all the possible categories effectively require attention." (Farooq, 2008, p. 50).

Note 6. Only if it is a product or contains stuff that is not in line with Shariah.

\section{Copyrights}

Copyright for this article is retained by the author(s), with first publication rights granted to the journal.

This is an open-access article distributed under the terms and conditions of the Creative Commons Attribution license (http://creativecommons.org/licenses/by/4.0/). 